\title{
Hubungan Kreativitas Mengajar Pendeta dengan Motivasi Belajar Anak Katekisasi Sidhi
}

\section{Andar Gunawan Pasaribu}

Prodi Pendidikan Agama Kristen, Institut Agama Kristen Negeri Tarutung, Sumatera Utara pdt.andargunawanpasaribu@yahoo.co.id

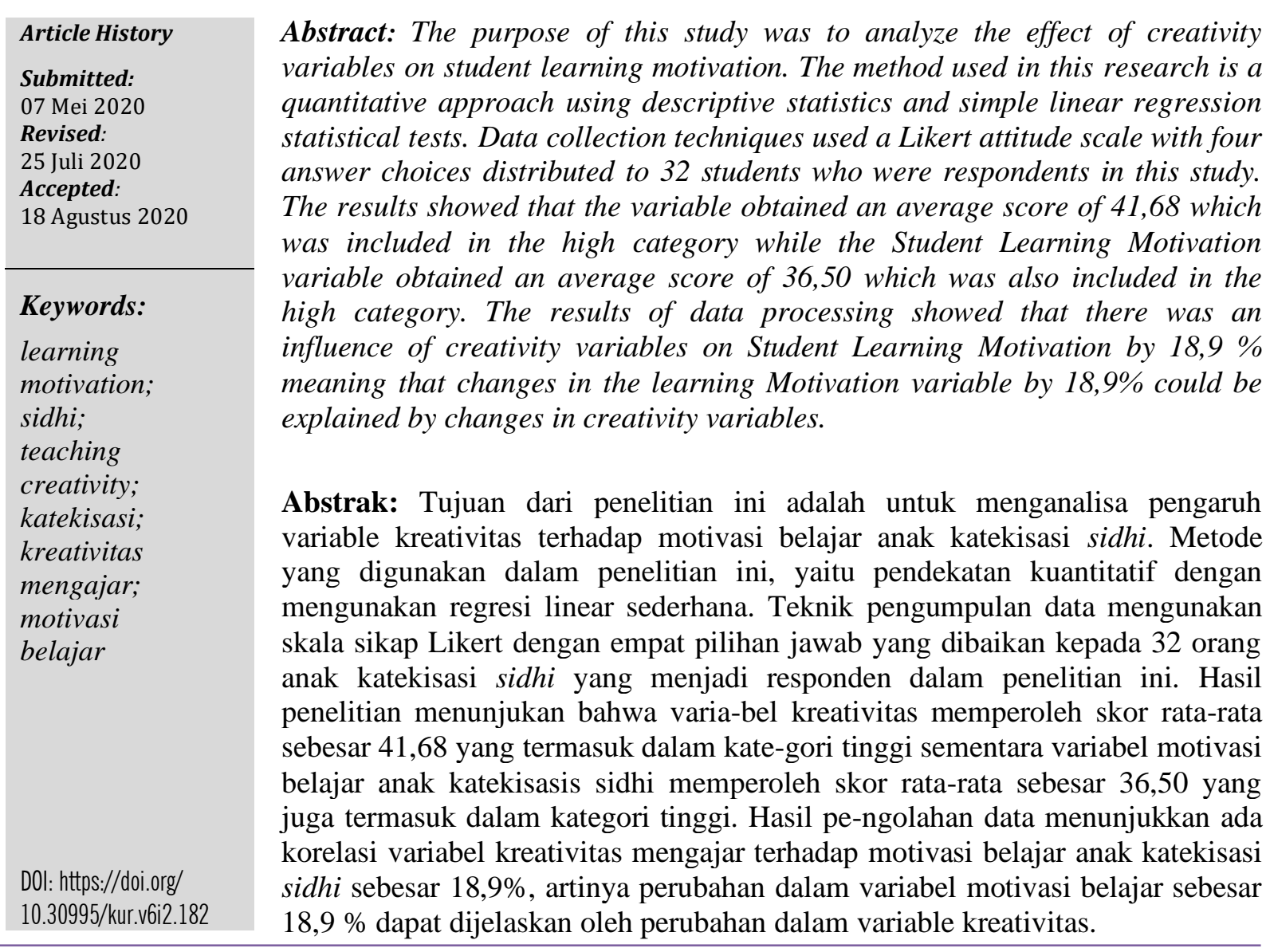

\section{Pendahuluan}

Pendeta merupakan seorang hamba Tuhan ${ }^{1}$, yang dalam tugasnya adalah melakukan pemberitaan Injil, menggembalakan, mengajar, membimbing untuk memperlengkapi orangorang kudus bagi pekerjaan pelayanan, bagi pembangunan tubuh Kristus, sampai semua telah mencapai kesatuan iman dan pengetahuan yang benar tentang Anak Allah. ${ }^{2}$ Katekisasi sidhi merupakan bagian kegiatan pokok dari keseluruhan proses pendidikan gereja, maka pendidikan gereja merupakan suatu usaha atau proses untuk meningkatkan kualitas manusia dengan jalan membina potensi pribadi, baik secara rohani maupun secara jasmani. Porter

${ }^{1}$ H.L Selduk, Pedoman Pelayanan Pendeta (Jakarta: YKBK/OMF, 2008), 38.

${ }^{2}$ Kantor Pusat GKPI, Agenda GKPI (Pematangsiantar: Kolportase GKPI, 2010), 94 Kantor Pusat GKPI, Agenda GKPI (Pematangsiantar: Kolportase GKPI, 2010), 94 
menyatakan kata "katekisasi" berasal dari bahasa Yunani, artinya "pelajaran", yang mana istilah ini sudah la-ma dipakai untuk pelajaran yang diberikan kepada siapa saja yang mau mengakui dan menerima iman Kristen. ${ }^{3}$ F.D. Wellem mengatakan, bahwa katekisasi berasal dari kata "katekese", yang artinya penga-jaran yang diberikan kepada calon baptisan. ${ }^{4}$ Tujuan Katekisasi Sidhi adalah pendidikan atau pembinaan anggota-anggota jemaat untuk menyadari tugas-tugas mereka di dalam gereja, di mana gereja adalah sebuah persekutuan orang-orang kudus di dunia. ${ }^{5}$ Oleh karena itu, G. Riemer menyatakan bahwa katekisasi yang berasal dari kata katehkhein berarti memberitahukan sesuatu dengan wibawa dan cara dialogis. ${ }^{6}$

Seorang calon yang akan mengikuti katekisasi, ketika mendaftar ke gereja, mereka selalu ditanyakan tentang motivasi yang membuat mereka mengikuti katekisasi. Sebagian kecil mereka, calon katekumen, memberikan jawaban dengan mengatakan bahwa mereka mengalami sebuah pengalaman rohani yang mendorong mereka untuk mengembangkan pengetahuan Alkitab dan pengetahuan rohani. Namun, selain itu juga, tidak sedikit anak yang kurang termotivasi belajar katekisasi. Sebagian besar dari mereka yang kurang termotivasi mengatakan karena paksaan orang tua. ${ }^{7}$ Ada yang menganggap kurangnya motivasi calon katekumen karena kurangnya krea-tivitas dalam mengajar sehingga anak-anak bosan. Artinya, ada keinginan para calon katekumen agar para pendeta meningkatkan kekreativas mengajar, khususnya untuk mengajar anak sidhi. ${ }^{8}$ Hal itu dianggap dapat meningkatkan motivasi anak mengikuti kelas sidhi.

Motivasi belajar adalah suatu proses untuk menggiatkan motif atau daya menjadi perbua-tan atau tingkah laku untuk memenuhi kebutuhan dan menjacapai tujuan tertentu. Kata Motivasi dalam Perjanjian Lama memakai kata mitsby, sementara dalam Perjanjian Baru memakai kata kinopro. ${ }^{9}$ Menurut Donald, yang dikutip oleh Djamarah, motivasi adalah suatu perubahan energi didalam pribadi seseorang yang ditandai dengan timbulnya efektif (perasan) dan reaksi untuk mencapai tujuan. ${ }^{10}$ Sidjabat menyatakan kemampuan menciptakan suasana belajar yang baik dan menyenangkan oleh guru menjadi faktor motivasi kuat bagi kelangsungan peristiwa belajar. ${ }^{11}$ Sedangkan motivasi belajar, menurut Saputra, memiliki indikator tekun menghadapi tugas, me-nunjukkan minat terhadap bermacam-macam masalah, tidak cepat bosan pada tugas yang rutin, dapat mempertahankan pendapatnya, tidak mudah melepaskan hal-hal yang diyakini. ${ }^{12}$

Terkait dengan motivasi belajar, ada banyak penelitian yang sudah dilakukan, seperti Iik Faiqotul Ulya, yang mengemukakan bahwa pembelajaran dengan kreativitas guru melalui

${ }^{3}$ Porter R.J, Katekisasi Masa Kini (Jakarta: YKBK/OMF, 1987), 37.

${ }^{4}$ Kannit Smith, Buku Panduan Untuk Pelayanan Sidi (Jakarta: The Lutheran World Federation, 2000), 40.

${ }^{5}$ JL.CH Abineno, Sekitar Katekisasi Gereja (Jakarta, 1987), 100.

${ }^{6}$ Riemer G. Ajarlah Mereka Melakukan, Jakarta: YKBK, 2006, hl33

${ }^{7}$ Abineno, Sekitar Katekisasi Gereja.

${ }^{8}$ G. D. Dahlenburg, Siapakah Pendeta Itu? (Jakarta: BPK Gunung Mulia, 1985), 12.

${ }^{9}$ Andar gunawan Pasaribu, Pendekatan Psikologi Pendidikan Agama Kristen (Medan: Penerbit Mitra, 2018), 121.

${ }^{10}$ Djamarah Syaiful Bahri, Psikologi Belajar (Jakarta, 2011), 148.

${ }^{11}$ B.S.Sijabat, Mengajar Secara Profesional (Bandung: Yayasan Kalam Hidup, 2010), 85.

${ }^{12}$ Yudha Nata Saputra, "Hubungan Spiritualitas Terhadap Motivasi Belajar Mahasiswa," KURIOS (Jurnal Teologi dan Pendidikan Agama Kristen) 6, no. 1 (2020): 1-17. 
pen-dekatan kontekstual lebih baik secara signifikan daripada pembelajaran konvensional dalam meningkatkan kemam-puan koneksi matematis siswa dan motivasi belajar siswa; serta terdapat hubungan positif antara kemampuan koneksi matematis dan motivasi belajar. ${ }^{13} \mathrm{Di}$ tempat lain, Lidia menekankan adanya pengaruh kreativitas guru dengan motivasi belajar. ${ }^{14}$ Motivasi anak katekisasi sidhi dapat dibangun melalui kreativitas pendeta dalam pembelajaran katekisasi Sidhi. Usaha peningkatan motivasi belajar anak kateiksasi sihdi tidak terlepas dari kekreativas dalam metode dan strategi pembelajaran, dan pendekatan anak dengan pertimbangan perbedaan anak katekisasi sidhi.

Sementara itu, kreativitas adalah kemampuan untuk menghasilkan cara, konsep, pengertian dan penemuan baru. Ini sesuai dengan pengertian umum kreativitas yang disampaikan James C. dan Coustances L. Hammer yang dikutip oleh Sumiyatiningsih, kreativitas adalah berpikir yang meghasilkan cara, konsep, pengertian, penemuan, dan karya seni yang baru. ${ }^{15}$ Sementara menu-rut Widiasworo, kreatif adalah yang selalu menggunakan ide-ide baru dalam menyajikan pem-belajaran di kelas sehingga lebih menarik bagi anak Sidhi dan tidak membosankan. ${ }^{16}$ Menurut Lusita, mengajar kreatif dapat diartikan bahwa guru tak pernah puas dengan apa yang disampai-kannya kepada peserta didik, sehingga selalu berusaha membuat cara-cara baru yang dapat me-ngembangkan motivasi belajar anak. ${ }^{17}$ Melihat kenyataan di lapangan, tampak bahwa kreativitas mengajar merupakan faktor yang penting karena akan mengarahkan motivasi anak dalam melak-sanakan studinya. Umi Musrifah mengungkapkan adanya hubungan yang sangat signifikan anta-ra kreativitas mengajar dengan motivasi belajar. ${ }^{18}$

Berdasarkan kajian-kajian terdahulu, maka penelitian ini mengajukan sebuah pemikiran tentang adanya korelasi antara kreativitas mengajar pendeta dengan motivasi katekumen mengi-kuti katekisasi sidhi.

\section{Metode Penelitian}

Pendekatan yang digunakan dalam penelitian ini adalah pendekatan kuantitatif. Penelitian ini termasuk jenis penelitian korelasi, yang bertujuan untuk mengetahui hubungan antara kreativitas mengajar pendeta dengan motivasi belajar anak katekisasi sidhi. Pendekatan kuantitatif dengan metode Ex Post Facto, hal ini sesuai dengan tujuan dari penelitian ini, yaitu untuk menganalisis hubungan variabel kreativitas terhadap variabel motivasi belajar anak katekisasi sidhi. Dalam rangka mendapatkan data yang dibutuhkan, maka variabelvariabel dalam penelitian ini perlu dioperasionalisasikan ke dalam indikator-indikator yang dapat diukur sehingga menggambarkan jenis data dan informasi yang diperlukan.

\footnotetext{
${ }^{13}$ Iik Faiqotul Ulya, Riana Irawati, and Maulana Maulana, "Peningkatan Kemampuan Koneksi Matematis Dan Motivasi Belajar Siswa Menggunakan Pendekatan Kontekstual,” Jurnal Pena Ilmiah 1, no. 1 (2016): 121130.

${ }^{14}$ Iik Faiqotul Ulya, Riana Irawati, "Peningkatan Kemampuan Koneksi Matematis Dan Motivasi Belajar Siswa Menggunakan Pendekatan Kontekstual"

${ }^{15}$ Sumiyati Ningsih, Mengajar Dengan Kreatif Dan Menarik (Yogyakarta, 2006), 135.

${ }^{16}$ Erwin Widiasworo, .. Rahasia Menjadi Guru Idola (Yogyakarta: Ar-Ruzz Media, 2014), 58.

${ }^{17}$ Afrisanti. Lusita, Buku Pintar Yang Menjadi Guru Kreatif, Inspiratif Dan Inofatif (Jakarta: Araskah,
} 2011), 53 .

${ }^{18}$ G. Amaral et al., "Hubungan Positip Dan Signifikan,” Journal of Petrology 369, no. 1 (2013): 75. 
Berdasarkan jenis data dan informasi tersebut maka dilakukan analisa secara statistik untuk bisa menjawab masalah yang telah dirumuskan dalam pe-nelitian ini.

Dalam rangka memudahkan pengumpulan data, pengukuran dan analisa data maka varia-bel dalam penelitian ini perlu dioperasionalisasikan. Merujuk kepada pendapat Berikut ini merupakan indikator kreativitas mengajar guru menurut Wulandari: Guru dapat menciptakan metode dan media yang dapat membuat anak bersemangat dalam belajar, Guru dapat menumbuhkan antusias belajar siswa. Guru harus bisa memberikan semangat belajar baik di dalam kelas maupun luar kelas bagi para siswa, Mengembangkan program membaca yang baik, dapat Terapkan teknik pemecahan masalah, dan melakukan penilaian yang berbeda atau bervariasi, ${ }^{19}$

Tabel 1: Operasionalisasi Variabel

\begin{tabular}{|c|c|c|}
\hline Variabel & Dimensi & Indikator \\
\hline \multirow{5}{*}{ Kreativitas } & $\begin{array}{l}\text { Menciptakan metode dan media } \\
\text { yang dapat memberi semangat } \\
\text { belajar }\end{array}$ & $\begin{array}{l}\text { - Metode yang bervariasi } \\
\text { - Media yang bervariasi } \\
\text { - Strategi yang bervariasi }\end{array}$ \\
\hline & $\begin{array}{l}\text { Dapat menumbuhkan antusias } \\
\text { belajar anak }\end{array}$ & $\begin{array}{l}\text { - Menemukan tujuan hidup } \\
\text { - Hidup bertanggung jawab } \\
\text { - Memperjuangkan tujuan hidup }\end{array}$ \\
\hline & $\begin{array}{l}\text { Mengembangkan program } \\
\text { membaca yang baik }\end{array}$ & $\begin{array}{l}\text { - Membaca yang baik } \\
\text { - Menghapal yang baik } \\
\text { - Menganalisa yang baik }\end{array}$ \\
\hline & $\begin{array}{l}\text { Menerapkan teknik pemecahan } \\
\text { masalah dengan baik }\end{array}$ & $\begin{array}{l}\text { - Menganalisa masalah dengan baik } \\
\text { - Mencari pemecahan masalah dengan baik } \\
\text { - Menerapkan teknik masalah dengan baik }\end{array}$ \\
\hline & Memberikan penilaian yang variatif & $\begin{array}{l}\text { - Penilaian system sokor } \\
\text { - Penilaian system pujian }\end{array}$ \\
\hline
\end{tabular}

Sedangkan dimensi dari variabel motivasi belajar merujuk kepada pendapat Sardiman, yaitu: tekun menghadapi tugas, menunjukkan minat terhadap bermacam- macam masalah, cepat bosan pada tugas-tugas yang rutin, dapat mempertahankan pendapatnya, tidak mudah melepaskan hal-hal yang diyakini. ${ }^{20}$

\begin{tabular}{|l|l|l|}
\hline Variabel & Dimensi & Indikator \\
\hline & Tekun menghadapi tugas & - Intensitas Belajar \\
& & - Keinginan menyelesaikan tugas \\
Motivasi & Minat terhadap masalah & - Berusaha keras \\
\cline { 2 - 3 } Belajar & & - Keinginan untuk terus belajar \\
& & - Senang kepada hal baru \\
\hline
\end{tabular}

\footnotetext{
${ }^{19}$ Mencapai Gelar, Sarjana Pendidikan, and Agama Islam, "Diajukan Kepada Fakultas Ilmu Tarbiyah Dan Keguruan Untuk Memenuhi JURUSAN PENDIDIKAN AGAMA ISLAM” (2010): 23.

${ }^{20}$ A.M.Sardiman, Interaksi Dan Motivasi Belajar Mengajar (Jakarta: Rajawali Press, 2011), 83-85.
} 


\begin{tabular}{|l|l|l|}
\hline Bosan pada tugas rutin & $\begin{array}{l}- \text { Malas hanya mendengarkan yang monoton } \\
-\end{array}$ \\
& - Menemukan cara-cara baru \\
\cline { 2 - 3 } & Mempertahankan Pendapatnya & - Senang Berdiskusi \\
& - Menjelaskan pendapatnya \\
\cline { 2 - 4 } & Sulit melepaskan keyakinannya & - Memperjuangkan keyakinannya \\
& - Membuktikan keyakinannya \\
\hline
\end{tabular}

Teknik analisis data dalam penelitian ini menggunakan statistik. Statistik yang digunakan dalam penelitian ini meliputi analisis deskriptif (mean, median, modus, standar deviasi), uji prasyarat (uji normalitas, uji linieritas), dan uji hipotesis (Korelasi Product Moment).

Pengumpulan data mengunakan teknik penelitian dengan kuesioner, teknik ini digunakan karena data yang diungkap berupa persepsi anak katekisasi sidhi . Untuk mengungkap data yang diperlukan digunakan dua skala sikap, yaitu skala sikap untuk mengungkap kreativitas dan motivasi belajar anak katekisasi sidhi yang dikembangkan dalam bentuk pernyataan tertutup, dengan empat alternatif jawaban, yaitu sangat setuju, setuju, tidak setuju dan sangat tidak setuju. Untuk pernyataan positif, masing-masing alternatif jawaban diberi skor 4, 3, 2, 1 sedangkan untuk item negatif diberi skor sebaliknya. Pengukuran variabel kreativitas mengajar dan motivasi belajar melalui rating technique dengan teknik Likert Sumatied Ratings Scale dengan empat skala. Dengan pertimbangan bahwa skala Likert lima skala akan memunculkan kategori Un-deciden dan menimbulkan kecenderungan jawaban ke tengah (central tendency effect). ${ }^{21}$ Adapun masing masing bobot jawaban, jawaban sangat setuju (SS) diberi bobor 4, jawaban setuju (S) diberi bobot 3, jawaban tidak setuju (TS) diberi bobot 2, dan jawaban sangat tidak setuju (STS) diberi bobot 1, sementara untuk item pernyataan negatif diberi bobot sebaliknya. Setelah setiap jawaban responden diberi bobot, lalu dijumlahkan sehingga diperoleh skor jawaban setiap responden. Selanjutnya untuk mengelompokkan jawaban responden maka dibuat rentang menjadi tiga kelompok, tinggi, sedang dan rendah, dengan menggunakan rumus di bawah ini:

Tabel 2: Kategori Skor 22

\begin{tabular}{|l|l|}
\hline Rendah & $\mathrm{X}<\mathrm{M}-1 \mathrm{SD}$ \\
\hline Sedang & $\mathrm{M}-1 \mathrm{SD}<\mathrm{X}<\mathrm{M}+1 \mathrm{SD}$ \\
\hline Tinggi & $\mathrm{M}+1 \mathrm{SD}<\mathrm{X}$ \\
\hline
\end{tabular}

Keterangan:

$\mathrm{M}=$ Mean

$\mathrm{SD}=$ Standard Deviasi

Sebelumnya, semua pernyataan sikap telah diujicobakan dahulu ke lapangan untuk menguji vali-ditas butir item dan reliabilitas instrumen. Hasil uji validitas untuk item pernyataan variabel kreativitas mengajar, ditunjukkan oleh tabel di bawah ini:

\footnotetext{
${ }^{21}$ Saputra, "Hubungan Spiritualitas Terhadap Motivasi Belajar Mahasiswa."

${ }^{22}$ Saifuddin Azwar, Penyusunan Skala Psikologi (Yogyakarta: Pustaka Pelajar, 2012), 25.
} 
Tabel 3: Perbandingan Nilai $r$ hitung dengan $r$ tabel Kreativitas Mengajar

\begin{tabular}{|l|c|c|c|c|}
\hline No. Item & $r$ hitung & $r$ tabel & Perbandingan & Keterangan \\
\hline 1. & 0,704 & 0,632 & $r$ hitung $>r$ tabel & Valid \\
\hline 2. & 0,761 & 0,632 & $r$ hitung $>r$ tabel & Valid \\
\hline 3. & 0,899 & 0,632 & $r$ hitung $>r$ tabel & Valid \\
\hline 4. & 0,879 & 0,632 & $r$ hitung $>r$ tabel & Valid \\
\hline 5. & 0,823 & 0,632 & $r$ hitung $>r$ tabel & Valid \\
\hline 6. & 0,764 & 0,632 & $r$ hitung $>r$ tabel & Valid \\
\hline 7. & 0,766 & 0,632 & $r$ hitung $>r$ tabel & Valid \\
\hline 8. & 0,856 & 0,632 & $r$ hitung $>r$ tabel & Valid \\
\hline 9. & 0,663 & 0,632 & $r$ hitung $>r$ tabel & Valid \\
\hline 10. & 0,672 & 0,632 & $r$ hitung $>r$ tabel & Valid \\
\hline 11. & 0,681 & 0,632 & $r$ hitung $>r$ tabel & Valid \\
\hline 12. & 0,848 & 0,632 & $r$ hitung $>r$ tabel & Valid \\
\hline 13. & 0,814 & 0,632 & $r$ hitung $>r$ tabel & Valid \\
\hline 14. & 0,768 & 0,632 & $r$ hitung $>r$ tabel & Valid \\
\hline 15. & 0,723 & 0,632 & $r$ hitung $>r$ tabel & Valid \\
\hline
\end{tabular}

Pengujian reliabilitas item pernyataan variabel kreativitas dilakukan dengan membandingkan angka Cronbach Alpha dengan ketentuan nilai minimalnya adalah 0.632 maka instrumen dika-takan reliabel. Hasil pengujian menunjukkan nilai Cronbach Alpha diperoleh, sebesar 0.632 , yang berarti item-item pernyataan yang digunakan dalam penelitian ini reliabel. Sementara itu, hasil uji validitas untuk item pernyataan variabel Motivasi Belajar Mahasiswa, dapat dilihat pada tabel di bawah ini:

Tabel 4: Perbandingan Nilai $r$ hitung dengan $r$ tabel Motivasi Belajar

\begin{tabular}{|l|c|c|c|c|}
\hline No. Item & $r$ hitung & $r$ tabel & Perbandingan & Keterangan \\
\hline 1. & 0,741 & 0,632 & $r$ hitung $>r$ tabel & Valid \\
\hline 2. & 0,778 & 0,632 & $r$ hitung $>r$ tabel & Valid \\
\hline 3. & 0,816 & 0,632 & $r$ hitung $>r$ tabel & Valid \\
\hline 4. & 0,666 & 0,632 & $r$ hitung $>r$ tabel & Valid \\
\hline 5. & 0,678 & 0,632 & $r$ hitung $>r$ tabel & Valid \\
\hline 6. & 0,839 & 0,632 & $r$ hitung $>r$ tabel & Valid \\
\hline 7. & 0,793 & 0,632 & $r$ hitung $>r$ tabel & Valid \\
\hline 8. & 0,876 & 0,632 & $r$ hitung $>r$ tabel & Valid \\
\hline 9. & 0,656 & 0,632 & $r$ hitung $>r$ tabel & Valid \\
\hline 10. & 0,674 & 0,632 & $r$ hitung $>r$ tabel & Valid \\
\hline 11. & 0,668 & 0,632 & $r$ hitung $>r$ tabel & Valid \\
\hline 12. & 0,655 & 0,632 & $r$ hitung $>r$ tabel & Valid \\
\hline 13. & 0,856 & 0,632 & $r$ hitung $>r$ tabel & Valid \\
\hline 14. & 0,832 & 0,632 & $r$ hitung $>r$ tabel & Valid \\
\hline 15. & 0,671 & 0,632 & $r$ hitung $>r$ tabel & Valid \\
\hline
\end{tabular}

Kemudian pengujian reliabilitas item pernyataan variabel Motivasi Belajar anak katekisasi sidhi dilakukan dengan membandingkan angka Cronbach Alpha dengan ketentuan nilai Cronbach Alpha minimal 0.6, maka item pernyataan dikatakan reliabel. ${ }^{23}$ Hasil pengujian menunjukkan nilai Cronbach Alpha diperoleh, sebesar 0.632, artinya item-item pernyataan yang digunakan dalam penelitian variabel Motivasi Belajar anak katekisasi sidhi dalam penelitian ini reliabel.

\footnotetext{
${ }^{23}$ Azwar, Penyusunan Skala Psikologi.
} 
Hubungan variabel kreativitas mengajar dengan variabel motivasi belajar anak katekisasi sidhi, dapat dianalisa dengan menggunakan uji regresi linier sederhana. Uji regresi linier seder-hana, dilakukan dengan data berdistribusi normal dan linier, untuk itu sebelum dilakukan uji regresi terlebih dahulu dilakukan uji normalitas dan linieritas. Setelah itu, dilakukan pengujian regresi linier sederhana sehingga terbentuk persamaan regresi $Y=a+b X$. Untuk mengetahui signifikan tidaknya koefisien regresi yang terbentuk dilakukan pengujian hipotesis.

Adapun yang menjadi hipotesis dalam penelitian ini, yaitu: $\mathrm{H} 0=$ Tidak ada pengaruh yang signifikan variabel kreativitas mengajar (X) terhadap variabel motivasi belajar anak katekisasi sidhi (Y). Ha=Ada pengaruh yang signifikan variabel kreativitas mengajar (X) terhadap variabel motivasi belajar anak katekisasi sidhi (Y). Keputusan diterima tidaknya hipotesis dapat dilaku-kan dengan membandingkan nilai Sig. dengan 0.05. Jika nilai signifikansi (Sig.) $<0.05$ artinya ada pengaruh yang signifikan variabel kreativitas mengajar (X) terhadap variabel motivasi be-lajar anak katekisasi sidhi (Y). Jika nilai signifikansi (Sig.) $>0.05$ artinya tidak ada pengaruh yang signifikan variabel kreativitas mengajar (X) terhadap variabel motivasi belajar anak kate-kisasi sidhi (Y). Kemudian untuk mengetahui besar pengaruh variabel Kreativitas Mengajar (X) terhadap variabel motivasi belajar anak katekisasi Sidhi, dilakukan dengan melihat hasil $R$ Square. Dalam rangka keakuratan data dan mempermudah perhitungan maka analisa data dalam penelitian ini dilakukan dengan menggunakan software SPSS ver 24.00.

\section{Hasil dan Pembahasan}

Dari hasil Variabel Kreativitas mengajar dalam penelitian ini, memperoleh skor rata-rata sebesar 41,68 yang termasuk dalam kategori tinggi, namun masih ada dua yang kurang dari skor ideal yang perlu ditingkatkan dengan memiliki skor 35. Ada 20 indikator (35\%) yang menunjukkan kreativitas mengajar tergolong sedang, dan 10 (30,06\%) dari indikator yang menunjukkan krea-tivitas mengajar tinggi.

\section{Tabel 5: Kreativitas Mengajar}

\begin{tabular}{|l|c|c|}
\hline Kategori & Frekuensi & Prosentase (\%) \\
\hline Tinggi & 10 & 31,2 \\
\hline Sedang & 20 & 62,5 \\
\hline Rendah & 2 & 6,3 \\
\hline Total & 32 & 100 \\
\hline
\end{tabular}

Kreativitas mengajar dalam penelitian ini, diukur oleh lima indikator, yaitu: menciptakan metode media yang dapat memberi semangat belajar, dapat menumbuhkan antusias belajar anak, mengembangkan membaca yang baik, menerapkan pemecahan masalah dengan baik dan memberi-kan penilaian yang variatif. Secara rinci hasil penelitian terhadap indikatorindikator Kreativitas mengajar dapat dijelaskan seperti berikut: 


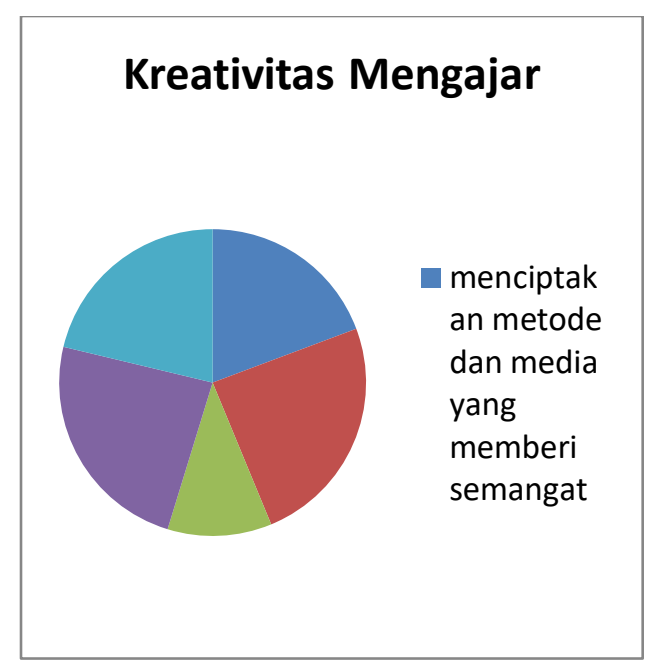

Berdasarkan tabel dan histogram di atas dapat diketahui bahwa tingkat kreativitas mengajar guru termasuk dalam kategori sedang dengan jumlah responden sebanyak 2 orang $(6,3 \%)$. Kategori rendah dengan jumlah responden sebanyak 20 (62,5\%) dan kategori tinggi dengan jumlah res-ponden sebanyak 10 (31,2\%). Hal ini menunjukkan bahwa kreativitas mengajar guru terhadap motivasi anak katekisasi termasuk dalam kategori sedang karena dalam tabel tersebut menunjuk-kan jumlah yang paling banyak.

Sedangkan Data diperoleh dari skala motivasi belajar kepada subjek penelitian yang ber-jumlah 32 orang. Jumlah butir skala motivasi belajar adalah 15 butir pernyataan dengan 4 pilihan jawaban (selalu, sering, kadang-kadang, tidak pernah). Skor perolehan tiap indikator disajikan dalam tabel sebagai berikut.

Tabel 6: Motivasi Belajar

\begin{tabular}{|l|c|c|}
\hline Kategori & Frekuensi & Prosentase (\%) \\
\hline Tinggi & 9 & $27,4 \%$ \\
\hline Sedang & 15 & 48,2 \\
\hline Rendah & 8 & 24,4 \\
\hline Total & 32 & 100 \\
\hline
\end{tabular}

Secara rinci hasil penelitian terhadap indikator-indikator motivasi belajar dapat dijelaskan seperti berikut:

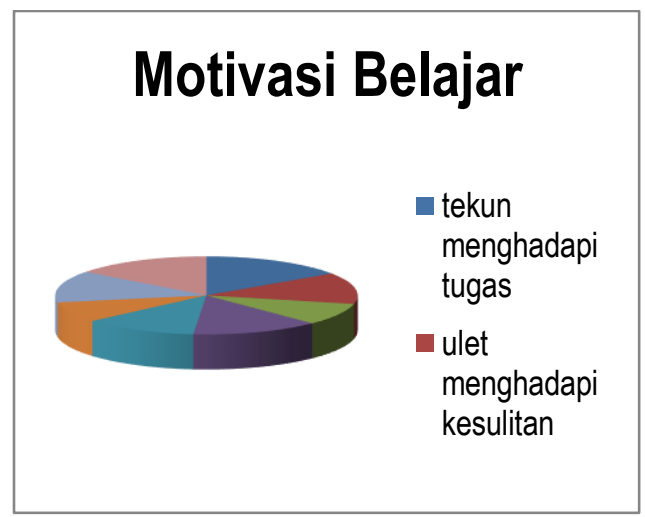

Berdasarkan tabel dan histogram di atas dapat diketahui bahwa tingkat motivasi belajar anak ter-masuk dalam kategori sedang dengan jumlah responden sebanyak 32 (36,50\%). Hal ini 
menun-jukkan bahwa motivasi belajar anak katekisasi termasuk dalam kategori sedang karena dalam ta-bel tersebut menunjukkan jumlah yang paling banyak.

Uji linieritas dan uji normalitas terlebih dahulu dilakukan sebelum sampai kepada uji regresi linier sederhana, untuk memastikan bahwa data layak diolah dengan menggunakan uji re-gresi linier sederhana. Tujuan Uji linieritas ialah untuk mengetahui apakah dua variabel mempu-nyai hubungan yang linier secara signifikan atau tidak. Pengambilan keputusan, dilakukan de-ngan membandingkan nilai signifikansi (Sig.) dengan 0.05. Jika nilai Deviation from Linearty Sig. > 0.05 maka ada hubungan yang linier secara signifikan antara variabel independent (Kreativitas Mengajar) dengan variabel dependent (Motivasi Belajar anak katekisasi sidhi ). Jika nilai Deviation from Linearty Sig. $<0.05$ maka tidak ada hubungan yang linier secara signifikan antara variabel independent (Kreativitas Mengajar) dengan variabel dependent (Motivasi Belajar). Hasil perhitungan menunjukkan bahwa nilai Deviation form Linearty Sig. sebesar $0.148>0.05$ sehingga dapat disimpulkan terdapat hubungan linier secara signifikan antara variabel Kreativitas (X) dengan variabel Motivasi Belajar anak katekisasi sidhi (Y).

Table 7: ANOVA

\begin{tabular}{|c|c|c|c|c|c|c|c|}
\hline & & & $\begin{array}{l}\text { Sum of } \\
\text { Squares }\end{array}$ & df & $\begin{array}{l}\text { Mean } \\
\text { Square }\end{array}$ & $\mathrm{F}$ & Sig. \\
\hline \multirow{5}{*}{$\begin{array}{l}\text { Motivasi Belajar * } \\
\text { Kreativitas } \\
\text { Mengajar }\end{array}$} & Between & (Combined) & 351.885 & 15 & 23.459 & 2.233 & .061 \\
\hline & \multirow{2}{*}{ Groups } & Linearity & 98.502 & 1 & 98.502 & 9.376 & .007 \\
\hline & & $\begin{array}{l}\text { Deviation from } \\
\text { Linearity }\end{array}$ & 253.384 & 14 & 18.099 & 1.723 & 148 \\
\hline & \multicolumn{2}{|c|}{ Within Groups } & 168.083 & 16 & 10.505 & & \\
\hline & \multicolumn{2}{|l|}{ Total } & 519.969 & 31 & & & \\
\hline
\end{tabular}

Langkah kedua Setelah dilakukan uji linieritas adalah melakukan uji normalitas OneSample Kolmogorov-Smirnov Test. Tujuan Uji normalitas One-Sample Kolmogorov-Smirnov Test untuk menguji apakah data dalam penelitian berdistribusi normal atau tidak, sebagai salah satu syarat untuk pengujian regresi linier sederhana. Jika nilai signifikansi (Sig.) lebih besar dari 0.05 maka data berdistribusi normal. Tetapi jika nilai signifikansi (Sig.) lebih kecil dari 0.05 maka data tidak berdistribusi normal. Hasil pengujian menunjukkan nilai signifikansi Asiymp.Sig (2-tailed) sebesar 0.200 lebih besar dari 0.05 sehingga dapat dikatakan data dalam penelitian ini berdistribusi normal.

Tabel 8: One-Sample Kolmogorov-Smirnov Test

\begin{tabular}{|c|c|c|c|}
\hline & Motivasi Belajar & Kreativitas Mengajar \\
\hline \multicolumn{2}{|l|}{$\mathrm{N}$} & 32 & 32 \\
\hline \multirow{2}{*}{$\begin{array}{l}\text { Normal } \\
\text { Parameters }{ }^{\mathrm{a}, \mathrm{b}}\end{array}$} & Mean & 36.4688 & 41.7188 \\
\hline & Std. Deviation & 4.09551 & 4.43763 \\
\hline \multirow{3}{*}{$\begin{array}{l}\text { Most Extreme } \\
\text { Differences }\end{array}$} & Absolute & .105 & .096 \\
\hline & Positive & .105 & .096 \\
\hline & Negative & -.087 & -.083 \\
\hline \multicolumn{2}{|l|}{ Test Statistic } & .105 & .096 \\
\hline \multicolumn{2}{|c|}{ Asymp. Sig. (2-tailed) } & $.200^{\mathrm{c}, \mathrm{d}}$ & $.200 \mathrm{c}, \mathrm{d}$ \\
\hline
\end{tabular}


Setelah pengujian terhadap linieritas dan normalitas data, maka dilakukan uji regresi linier sederhana untuk mengetahui besar pengaruh variabel kreativitas mengajar terhadap variabel motivasi belajar anak katekisasi sidhi (Y).

Table 9: Coefficients

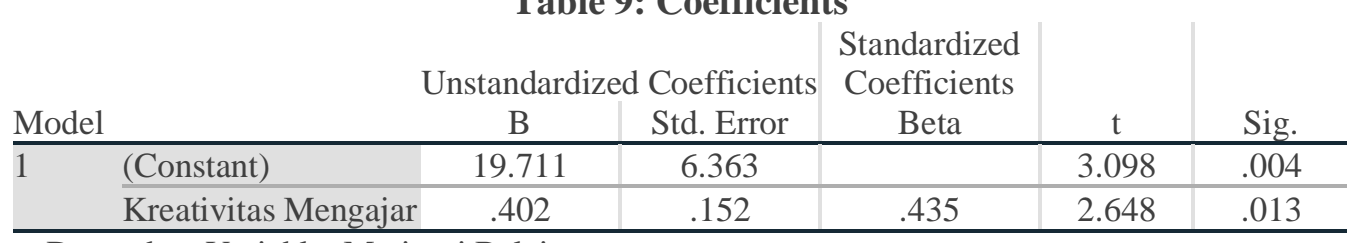

a. Dependent Variable: Motivasi Belajar

Bentuk persamaan linier sederhana dinyatakan dalam bentuk $\mathrm{Y}=\mathrm{a}+\mathrm{bX}$. Hasil pengolahan data menunjukkan a=angka konstan dari unstandardized coefficients sebesar 19,711, artinya jika tidak ada Kreativitas Mengajar (X), maka nilai konsisten motivasi belajar katekisasi sidhi sebesar 19,711. Sementara $b=$ angka koefisien regresi, yang nilainya dalam penelitian ini sebesar 0.402. Artinya, setiap penambahan 1\% tingkat Kreativitas Mengajar (X), maka motivasi belajar anak katekisasi sidhi (Y) akan meningkat sebesar 0.402. Karena nilai koefisien regresi bernilai positif maka dapat dikatakan bahwa Kreativitas Mengajar (X) memiliki pengaruh positif terhadap Motivasi Belajar anak katekisasi sidhi (Y), jadi persamaan regresi yang terbentuk dalam penelitian ini, yaitu $\mathrm{Y}=19,711+0.402 \mathrm{X}$.

Untuk mengetahui signifikan tidaknya koefisien regresi yang terbentuk maka perlu dilakukan uji hipotesis, di mana $\mathrm{H0}=$ Tidak ada pengaruh yang signifikan variabel Kreativitas Mengajar (X) terhadap variabel Motivasi Belajar anak katekisasi Sidhi (Y). Ha = Ada pengaruh yang signifikan variabel Kreativitas Mengajar (X) terhadap variabel motivasi belajar anak katekisasi Sidhi (Y). Jika nilai signifikansi (Sig.) $<0.05$, artinya ada pengaruh yang signifikan variabel Kreativitas Mengajar terhadap variabel motivasi belajar anak katekisasi Sidhi (Y). Jika nilai signifikansi (Sig.) > 0.04, artinya tidak ada pengaruh dari variabel Kreativitas Mengajar (X) terhadap variabel motivasi belajar anak katekisasi sidhi (Y). Nilai signifikansi pada tabel Coeffcients ${ }^{\mathrm{a}}$ menunjukkan angka $0.013<0.04$. Demikian pula nilai $\mathrm{t}$ hitung $(2,648)>\mathrm{t}$ tabel $(1.99254)$, sehingga dapat disimpulkan bahwa H0 ditolak dan Ha diterima, artinya "Ada pengaruh yang signifikan variabel Kreativitas Mengajar (X) terhadap variabel Motivasi Belajar anak katekisasi sidhi (Y).

Kemudian, untuk mengetahui besar pengaruh variabel Kreativitas Mengajar (X) terhadap variabel Motivasi Belajar Anak katekisasi sidhidapat dilakukan dengan melihat nilai $R$ Square.

\begin{tabular}{|c|c|c|c|c|}
\hline \multicolumn{5}{|c|}{ Tabel 10: Model Summary ${ }^{b}$} \\
\hline Model & $\mathrm{R}$ & R Square & $\begin{array}{c}\text { Adjusted R } \\
\text { Square }\end{array}$ & $\begin{array}{l}\text { Std. Error of the } \\
\text { Estimate }\end{array}$ \\
\hline 1 & $.435^{\mathrm{a}}$ & .189 & .162 & 3.74819 \\
\hline
\end{tabular}

Mencermati tabel di atas dapat diketahui nilai $R$ Square sebesar 0.189. Nilai ini mengandung arti bahwa pengaruh Kreativitas Mengajar (X) terhadap Motivasi Belajar anak katekisasi sidhi 
(Y) sebesar 18,9\%. Sedangkan sisanya sebesar 81,1\% Motivasi Belajar anak kateiksasi sidhi dipengaruhi oleh variabel lain yang tidak diteliti dalam penelitian ini.

\section{Diskusi}

Kreativitas mengajar guru mempunyai hubungan positif dan signitfikan dengan motivasi belajar siswa. ${ }^{24}$ Untuk membangkitkan motivasi belajar siswa, guru perlu memperhatikan halhal di antaranya, siswa akan belajar lebih giat apabila topik yang dipelajarinya menarik dan berguna bagi dirinya, tujuan pembelajaran harus disusun dengan jelas dan diinformasikan kepada siswa, siswa harus selalu diberitahu tentang hasil belajarnya, pemberian pujian dan hadiah lebih baik daripada hukuman, namun sewaktu-waktu hukuman juga diperlukan, memanfaatkan sikap, cita-cita, dan rasa ingin tahu siswa. ${ }^{25}$ Ini berarti bahwa kreativitas mengajar guru berhubungan bahkan berpengaruh terhadap motivasi belajar anak. Kenyataan ini mendapatkan dukungan dari hasil pembicaraan dengan beberapa anak katekisasi sidhi, bahwa mereka mengalami motivasi belajar katekisasi sidhi ketika merasakan ada hal yang kreatif dari guru, termasuk dalam metode mengajar, dalam pemecahan masalah dan pemberian penilai yang variatif.

Kenyataan di atas, tentunya akan memiliki implikasi terhadap kreativitas mengajar katekisasi Sidhi, yang perlu menekankan kepada pendidikan yang syarat nilai, berbeda dengan pendidikan modern yang menganut pandangan bebas dari nilai-nilai (value free) lokal masyarakat $^{26}$, sehingga iman, nilai-nilai agama dan moralitas perlu menjadi tekanan dalam pendidikan katekisasi sidhi. Hal ini sesuai dengan tujuan katekisasi merupakan salah satu bentuk pelayanan pendidikan Kristiani yang dilakukan oleh gereja. Katekisasi yang diberikan kepada remaja sangat penting sekali untuk mempersiapkan mereka sebagai generasi penerus ke jenjang yang lebih dewasa untuk berbuat baik bagi dirinya, keluarga dan masyarakat. Dalam katekisasi sidi remaja juga dibimbing menuju kepada kedewasaan iman sebagai manusia yang beragama. $^{27}$

Dengan membandingkan antara hasil penelitian yang dilakukan oleh Istiqomah Nur 'Aliyah dengan hasil penelitian ini, ditemukan perbedaan kecenderungan hasil variabel kreativitas mengajar, di mana hasil penelitian yang dilakukan oleh Istiqomah Nur menemukan kecenderungan kreativitas guru yang tinggi, sementara dalam penelitian ini menemukan kecenderungan motivasi belajar yang tinggi. Perbedaan ini terjadi karena, perbedaan tempat, responden penelitian dan aspek kreativitas mengajar yang diukur. Responden dalam penelitian Istiqomah Nur adalah anak Sekolah Dasar, sementara responden dalam penelitian ini adalah anak remaja gereja. Namun, dari hasil penelitian kelemahan kreativitas mengajar yang lemah pada kurangnya kreativitas mengembangkan program membaca anak sebesar $15 \%$.

Dilihat dari hasil perhitungan yang telah peneliti lakukan, begitu pengaruh motivasi belajar anak katekisasi sidhi sedang sebesar $42 \%$. Karena pentingnya pengaruh motivasi terha-

\footnotetext{
${ }^{24}$ Istiqomah Nur'Aliyah, "Hubungan Kreativitas Mengajar Guru Dengan Motivasi,” Jurnal Pendidikan Guru Sekolah Dasar 8, no. 6 (2017): 792-800.

${ }^{25}$ Amaral et al., "Hubungan Positip Dan Signifikan."

${ }^{26}$ Yudha Nata Saputra, "Hubungan Spiritualitas Dan Motivasi Belajar Mahasiswa Teologi," Kurios 6, no. 1 (2020): 1-17.

${ }^{27}$ Natasya Virginia Leuwol, "Pendidikan Katekisasi Kepada Remaja Di Jemaat Gki Kasih Perumnas Sorong,” Journal of Dedication to Papua Community 1, no. 1 (2019): 10.
} 
dap prestasi disini siswa harus dapat menumbuhkan dan mengembangkan motivasi belajar yang ada di dalam dirinya. Prestasi belajar menurut Slameto, "belajar adalah suatu proses usaha yang dilakukan seseorang untuk memperoleh suatu perubahan tingkah laku yang baru secara keseluruhan sebagai hasil pengalamannya sendiri sebagai hasil interaksi dengan lingkungannya." ${ }^{28}$ Dengan motivasi belajar anak katekisasi sidhi akan menambah pengetahuan dan perubahan tingkah laku baru sebagai hasil pengalaman dari pelajaran katekisasi sidhi.

Kenyataan di atas dapat terjadi karena mayoritas anak katekisasi yang belajar berasal bukan dari keluarga yang kurang memperhatikan pendidikan iman anak. Kedatangan mereka untuk belajar memberikan sumbangan terhadap tingginya motivasi belajar anak. Pengorbanan meninggalkan pekerjaan dan masa bermain menunjukkan bahwa faktor ini yang turut memperkuat motivasi belajar mereka. Dengan adanya motivasi belajar anak katekisasi sidhi ini juga menunjukkan bahwa mereka memiliki tekad yang kuat dan harapan untuk bisa belajar dengan baik. Dengan motivasi belajar ini tentunya menjadi modal utama yang baik untuk menunjang keberhasilan proses-belajar tentang firman Allah.

Oleh karena itu, proses pembelajaran katekisasi sidhi perlu untuk lebih banyak mengembangkan kemampuan iman anak dengan cara mengembangkan model belajar yang bersifat dialogis (student centered) dan variatif, dari pada pembelajaran yang sifatnya satu arah (teacher centered). Hal ini penting agar memberikan motivasi belajar tentang katekisasi sidhi. Katekisasi sidhi mampu meningkatkan kecerdasan spiritual anak. Salah satu kreativitas mengajar pendeta dengan motivasi belajar anak katekisasi sidhi dalam meningkatkan kecerdasan spiritual melalui pendekatan yang menekankan pendekatan religius instruksional. Tujuannya adalah untuk memampukan naradidik mendasarkan kehidupannya pada ajaran-ajaran Alkitab, dan membangun antara isi dan ajaran tersebut dengan kehidupan. Pendekatan pertumbuhan spiritualitas bertujuan membantu naradidik meningkatkan kehidupan diri mereka dan meresponnya dengan tindakan terhadap sesama dan dunia. Pendekatan komunitas iman bertujuan untuk membangun komunitas yang memperlihatkan perkembangan manusia yang otentik dan membangun komunitas, dan pendekatan transformasi yang bertujuan membantu naradidik dan komunitas untuk menunjukkan adanya perubahan sosial. ${ }^{29}$

\section{Kesimpulan}

Hasil penelitian menunjukkan bahwa terdapat pengaruh yang positif dan signifikan variabel kreativitas mengajar terhadap motivasi belajar anak katekisasi sidhi sebesar 18,9\%. Artinya, perubahan dalam variabel motivasi belajar anak katekisasi sidhi dapat dijelaskan sebesar $18,9 \%$ oleh variabel anak katekisasi sidhi, sementara $81,1 \%$ sisanya dipengaruhi oleh variabel lain yang tidak diteliti dalam penelitian ini. Hubungan kreativitas pendeta dengan motivasi belajar anak katekisasi Sidhi tahun 2020 ialah positif dan signifikan dengan $r_{x y}$ sebesar 0,435. Sedangkan nilai determinasinya $\mathbf{r}^{2}=0,5669$. Kepada peneliti selanjutnya, diharapkan mampu melakukan penelitian dengan sampel yang lebih besar dengan menggunakan metode penelitian lain sehingga bisa didapatkan bukti. Hasil penelitian ini sudah sesuai dengan tujuan dari

\footnotetext{
${ }^{28}$ Slameto, Belajar Dan Faktor-Faktor Yang Mempengaruhinya (Jakarta: Rineka Cipta, 2010), 32.

${ }^{29}$ Jack L Seymour, Memetakan Pendidikan Kristiani (Jakarta: BPK Gunung Mulia, 2010), 21.
} 
penelitian ini yaitu untuk menganalisis pengaruh variabel kreativitas mengajar terhadap motivasi belajar anak katekisasi Sidhi.

\section{Ucapan Terima Kasih}

Terima kasih kepada Guru Jemaat GKPI se-Resort GKPI Onan Runggu, Pnt. R. Batubara, Pnt. Maju Simanjuntak, yang telah memberikan ijin agar penelitian ini bisa berjalan dengan baik. Terima kasih kepada seluruh anak anak katekisasi Sidhi GKPI se-Resort Onan Runggu, Kecamatan Sipahutar, Tapanuli, yang telah meluangkan waktunya untuk mengisi instrumen penelitian dari mulai uji coba instrumen sampai kepada selesainya penelitian ini.

\section{Referensi}

A.M.Sardiman. Interaksi Dan Motivasi Belajar Mengajar. Jakarta: Rajawali Press, 2011. Abineno, JL.CH. Sekitar Katekisasi Gereja. Jakarta, 1987.

Amaral, G., J. Bushee, U. G. Cordani, KOJI KAWASHITA, J. H. Reynolds, Fernando FLÁVIO MARQUES De E ALMEIDA, F. F.M. de Almeida, et al. "Hubungan Positip Dan Signifikan." Journal of Petrology 369, no. 1 (2013): 1689-1699.

Azwar, Saifuddin. Penyusunan Skala Psikologi. Yogyakarta: Pustaka Pelajar, 2012. B.S.Sijabat. Mengajar Secara Profesional. Bandung: Yayasan Kalam Hidup, 2010. Dahlenburg, G. D. Siapakah Pendeta Itu? Jakarta: BPK Gunung Mulia, 1985.

Gelar, Mencapai, Sarjana Pendidikan, and Agama Islam. "Diajukan Kepada Fakultas Ilmu Tarbiyah Dan Keguruan Untuk Memenuhi JURUSAN PENDIDIKAN AGAMA ISLAM" (2010).

Leuwol, Natasya Virginia. "Pendidikan Katekisasi Kepada Remaja Di Jemaat Gki Kasih Perumnas Sorong." Journal of Dedication to Papua Community 1, no. 1 (2019): 32-41. Lusita, Afrisanti. Buku Pintar Yang Menjadi Guru Kreatif, Inspiratif Dan Inofatif. Jakarta: Araskah, 2011.

Ningsih, Sumiyati. Mengajar Dengan Kreatif Dan Menarik. Yogyakarta, 2006.

Nur'Aliyah, Istiqomah. "Hubungan Kreativitas Mengajar Guru Dengan Motivasi." Jurnal Pendidikan Guru Sekolah Dasar 8, no. 6 (2017): 792-800.

Pasaribu, Andar gunawan. Pendekatan Psikologi Pendidikan Agama Kristen. medan: Penerbit Mitra, 2018.

R.J, Porter. Katekisasi Masa Kini. Jakarta: YKBK/OMF, 1987.

Saputra, Yudha Nata. "Hubungan Spiritualitas Terhadap Motivasi Belajar Mahasiswa." KURIOS (Jurnal Teologi dan Pendidikan Agama Kristen) 6, no. 1 (2020): 1-17.

Selduk, H.L. Pedoman Pelayanan Pendeta. Jakarta: YKBK/OMF, 2008.

Seymour, Jack L. Memetakan Pendidikan Kristiani. Jakarta: BPK Gunung Mulia, 2010. Slameto. Belajar Dan Faktor-Faktor Yang Mempengaruhinya. Jakarta: Rineka Cipta, 2010. Syaiful Bahri, Djamarah. Psikologi Belajar. Jakarta, 2011.

Ulya, Iik Faiqotul, Riana Irawati, and Maulana Maulana. "Peningkatan Kemampuan Koneksi Matematis Dan Motivasi Belajar Siswa Menggunakan Pendekatan Kontekstual.” Jurnal Pena Ilmiah 1, no. 1 (2016): 121-130.

Widiasworo, Erwin. Rahasia Menjadi Guru Idola. Yogyakarta: Ar-Ruzz Media, 2014. 